\title{
Sample size formula for joint modelling of longitudinal and time-to-event data in clinical trials
}

\author{
Matthew Powney ${ }^{*}$, Paula Williamson, Ruwanthi Kolamunnage-Dona \\ From 2nd Clinical Trials Methodology Conference: Methodology Matters \\ Edinburgh, UK. 18-19 November 2013
}

In many clinical trials, longitudinal or repeated measures data is collected in order to monitor the patient's progress over time towards a clinical end-point. One method of accounting for the two outcomes is by using joint modelling methods. However, little work has been done on sample size calculations for studies which use joint modelling of longitudinal and time-to-event data to establish treatment effects. We propose a sample size formula based on the random effects formulation of the joint model. The method calculates the sample size and power based on the number of longitudinal time points by extending the Schoenfeld [1] approach to sample size for the proportional hazards model. We derive the required number of events using the score statistic [2] based on the random effects joint model [3].

Published: 29 November 2013

\section{References}

1. Schoenfeld D: Sample Size Formula for the Proportional-Hazards Regression Model. Biometrics 1983, 39:499-503.

2. Rao CR: Linear Statistical Inference and It's Applications. New York: Wiley; 1973.

3. Henderson R, Diggle P, Dobson A: Joint Modelling of longitudinal measurements and event time data. Biostatistics 2000, 1(4):465-480.

Submit your next manuscript to BioMed Central and take full advantage of:

- Convenient online submission

- Thorough peer review

- No space constraints or color figure charges

- Immediate publication on acceptance

- Inclusion in PubMed, CAS, Scopus and Google Scholar

- Research which is freely available for redistribution
() Bïmed Central
๑ 2013 Powney et al; licensee BioMed Central Ltd. This is an Open Access article distributed under the terms of the Creative Commons Attribution License (http://creativecommons.org/licenses/by/2.0), which permits unrestricted use, distribution, and reproduction in any medium, provided the original work is properly cited. 